Anaerobic cultures showed that species of Bacteroides were the predominant bacteria present during both restricted and ad lib. feeding. These appeared in Gram-films as two pleomorphic forms-mainly coccal in the presence of ciliates and rod-like during ad lib. intake.

Similar observations were made when two steers were changed from ad lib. to restricted intake and given an inoculum of rumen ciliates.

REFERENCE

Eadie, J. M., Hobson, P. N. \& Mann, S. O. (1967). Anim. Prod. 9, 247.

\title{
Preliminary communication on studies of the digestive processes in pigs with intestinal cannulas. By R. Braude, H. L. Buttle, F. Horszczaruk* and A. W. Myres, National Institute for Research in Dairying, Shinfield, Reading
}

The use of intestinal cannulas has been found to facilitate the study of digestive processes in the living pig and to allow repeated observations on the same animal. One or two single cannulas, and one or two re-entrant cannulas were fitted into the small intestines of pigs weighing $60-100 \mathrm{~kg}$. Preliminary observations were reported on the passage of the digesta, and particularly of nitrogen and polyethylene glycol (PEG) which was used as a marker. Movement of the digesta during the interval between two feeds showed two marked peaks, but very considerable variation between replicates from the same animal was observed. PEG was found unsatisfactory for tracing the passage of nitrogen, as it appears to leave the stomach faster than the solid material.

The influence of meat meal and other high-protein feeding-stuffs on the survival of chicks inoculated with Salmonella gallinarum. By R. HILL, Royal Veterinary College, University of London

The influence of level of dietary protein on infectious disease has been studied by a number of workers, often with conflicting results. Hill, Colburn \& Schneider (I962) showed that certain substances other than protein, present in the diet, could modify the protein effect, and recently it became evident that the source of protein also influenced the result (Hill \& Smith, I969).

In the experiments described here the total protein contents of the diets were similar, about $20 \%$, and near to the level recommended for chicks (National Research Council, 1966). For each diet one high-protein feeding-stuff was mixed with wheatmeal and an appropriate supplement of minerals, vitamins and amino acids to permit reasonably good growth in control chicks. From day-old to 12 days all chicks were

*Present address: Institute of Animal Physiology and Nutrition, Jablonna, Warsaw, Poland. 
given a semi-purified casein-gelatin diet $(26 \mathrm{~W})$, then changed to the experimental diets, and inoculated orally with Salmonella gallinarum 3 days later.

In each of four experiments the purified diet $(26 \mathrm{~W})$ was given throughout to one group of chicks and a meat-meal diet was also included as a second control: the percentage survival of chicks given meat meal in each experiment, 69, 50, 57 and 57 , was significantly greater than the corresponding value for diet $26 \mathrm{~W}, 22,2 \mathrm{I}, 24$ and 36 . In the same experiments groups of forty-two birds were given diets based on six other commonly used high-protein feeding-stuffs, and each was tested in two experiments. The mean percentage survival values were: dried separated milk, 46; groundnut-cake meal, I7; sunflower-seed meal, I4; fish meal, I4; cottonseed meal, Iо; and soya-bean meal, 2. None of the diets permitted the high survival given with meat meal, though dried separated milk gave almost as high a value; all the remaining diets gave percentage survival values poorer even than that of the purified diet.

\section{REFERENCES}

Hill, C. H., Colburn, R. W. \& Schneider, H. A. (1962). F. Nutr. 78, 424.

Hill, R. \& Smith, I. M. (I969). Proc. Nutr. Soc, 28, 5 A.

National Research Council. (I966.) Publs natn. Res. Coun., Wash. no. 1345.

*The metabolism of fluoroacetate by plants. By P. F. V. WARD and N. S. Huskisson, A.R.C. Institute of Animal Physiology, Babraham, Cambridge

*An organically combined fluorine compound in bone. By R. A. PETERS and M. Shorthouse, Department of Biochemistry, University of Cambridge and P. F. V. WARD, A.R.C. Institute of Animal Physiology, Cambridge

\section{Trypsin-inhibitory and growth-depressing activities of groundnut skins}

(testa). By K. Anantharaman, School of Agriculture, University of Cambridge

Borchers \& Ackerson (1947) and Woodham \& Dawson (1968) reported high values for the in vitro trypsin inhibitor activity (TIA) in raw, extracted groundnut flour (RGF) making use of the haemoglobin digestion technique of Anson (1938-9). Kwaan, Kok \& Astrup (1968) reported growth depression and pancreatic hypertrophy in rats fed a preparation of groundnut trypsin inhibitor. Our in vitro studies, however, showed that RGF has a TIA of only $4^{-5} \times 10^{-3}$ trypsin inhibitor units $/ \mathrm{mg}$, although for raw soya-bean meal (RSBM) our values were comparable to those reported by the other workers. Values for TIA of RGF and RSBM were in the same relative proportion as that observed by the hacmoglobin method, when $0.0025 \mathrm{~N}-\mathrm{HCl}$ extracts of the test materials were assayed by the synthetic substrate benzoyl, DL-arginine, p-nitroanilide (BAPA) method of Sambeth, Nesheim \& Serafin (1967). 